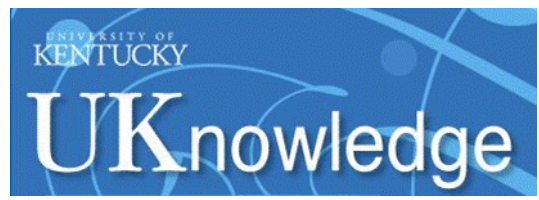

University of Kentucky

UKnowledge

Forestry and Natural Resources Faculty

Publications

Forestry and Natural Resources

$9-2020$

\title{
Occupancy and Abundance of Stream Salamanders along a Specific Conductance Gradient
}

\author{
Jacob M. Hutton \\ University of Kentucky, jakehutton@uky.edu \\ Steven J. Price \\ University of Kentucky, steven.price@uky.edu \\ Simon J. Bonner \\ University of Western Ontario, Canada \\ Stephen C. Richter \\ Eastern Kentucky University \\ Christopher D. Barton \\ University of Kentucky, barton@uky.edu
}

Follow this and additional works at: https://uknowledge.uky.edu/forestry_facpub

Part of the Natural Resources and Conservation Commons, and the Water Resource Management Commons

Right click to open a feedback form in a new tab to let us know how this document benefits you.

\section{Repository Citation}

Hutton, Jacob M.; Price, Steven J.; Bonner, Simon J.; Richter, Stephen C.; and Barton, Christopher D., "Occupancy and Abundance of Stream Salamanders along a Specific Conductance Gradient" (2020). Forestry and Natural Resources Faculty Publications. 46.

https://uknowledge.uky.edu/forestry_facpub/46

This Article is brought to you for free and open access by the Forestry and Natural Resources at UKnowledge. It has been accepted for inclusion in Forestry and Natural Resources Faculty Publications by an authorized administrator of UKnowledge. For more information, please contact UKnowledge@lsv.uky.edu. 
Occupancy and Abundance of Stream Salamanders along a Specific Conductance Gradient

\author{
Digital Object Identifier (DOI) \\ https://doi.org/10.1086/709688 \\ Notes/Citation Information \\ Published in Freshwater Science, v. 39, no. 3. \\ (C) 2020 by The Society for Freshwater Science
}

The copyright holder has granted the permission for posting the article here. 


\title{
Occupancy and abundance of stream salamanders along a specific conductance gradient
}

\author{
Jacob M. Hutton ${ }^{1,4}$, Steven J. Price ${ }^{1,5}$, Simon J. Bonner ${ }^{2,6}$, Stephen C. Richter ${ }^{3,7}$, \\ and Christopher D. Barton ${ }^{1,8}$ \\ ${ }^{1}$ Department of Forestry and Natural Resources, University of Kentucky, 105 T. P. Cooper Building, 730 Rose Street, Lexington, Ken- \\ tucky 40546 USA \\ ${ }^{2}$ Department of Statistical and Actuarial Sciences and Department of Biology, University of Western Ontario, Western Science Centre \\ Room 262, 1151 Richmond Street, London, Ontario, Canada N6A 5B7 \\ ${ }^{3}$ Department of Biological Sciences and Division of Natural Areas, Eastern Kentucky University, 521 Lancaster Avenue, 3106 New Sci- \\ ence Building, Richmond, Kentucky 40475 USA
}

\begin{abstract}
In the Central Appalachians (USA), mountaintop-removal mining accompanied by valley fills often leads to streams with elevated specific conductivity (SC). Thus, the ionic composition of freshwaters in this region is hypothesized to be a driver of the distribution and abundance of freshwater taxa, including stream salamanders. We examined the association between SC and stream salamander populations by conducting salamander counts in 30 southeastern Kentucky streams across a continuous gradient of SC that ranged from 30 to $1966 \mu \mathrm{S} / \mathrm{cm}$. We counted 2319 salamanders across 5 species and, using a hierarchical Bayesian version of the N-mixture model, found a negative association between SC and salamander occupancy rates. This finding was consistent across adults and larvae of the 5 species we examined. Furthermore, we found that most salamander species and life stages showed reduced abundances given occupancy at greater SC levels. For example, estimated mean abundance given occupancy of larval Southern Two-lined Salamanders (Eurycea cirrigera) was 67.69 (95\% credible interval 48.3198.25) ind $/ 10 \mathrm{~m}$ at $250 \mu \mathrm{S} / \mathrm{cm}$ and 2.30 (95\% credible interval $1.46-3.93$ ) ind $/ 10 \mathrm{~m}$ at $2000 \mu \mathrm{S} / \mathrm{cm}$. The consistent negative association across all species and life stages supports the hypothesis that salamander distributions and abundances are negatively associated with elevated SC of streams in southeastern Kentucky, even though physical and chemical environmental attributes, such as forest cover within stream catchments, were correlated with SC. Restoration of streams affected by mountaintop-removal mining should focus on restoring the ionic compositions that naturally occur in this region.
\end{abstract}

Keywords: amphibians, Appalachian, pollution, mining, salinization, water quality

Human-accelerated weathering of rocks and soils is shifting the ionic composition of freshwater systems (Kaushal et al. 2018). Land-cover change, particularly from mining and other resource extraction activities, is a major contributor to these changes in ionic composition (CañedoArgüelles et al. 2013). In the Central Appalachian Mountains (USA), mountaintop-removal mining is the primary driver of land-cover change (Bernhardt and Palmer 2011, Wickham et al. 2013). This type of surface mining involves the removal of large amounts of rock (i.e., mountaintops) to access coal seams. Unconsolidated rocky material, or overburden, is often discarded from the mine site into adjacent valleys, forming a valley fill (Bernhardt and Palmer 2011). Valley filling results in the partial burial of low-order streams, and surface waters that emerge from the fill area have elevated levels of major ions, including sodium $\left(\mathrm{Na}^{+}\right)$, calcium $\left(\mathrm{Ca}^{+2}\right)$, magnesium $\left(\mathrm{Mg}^{+2}\right)$, potassium $\left(\mathrm{K}^{+}\right)$, chloride, sulfate $\left(\mathrm{SO}_{4}{ }^{-2}\right)$, carbonates, and bicarbonates (Palmer et al. 2010, Griffith et al. 2012). Thus, freshwater systems influenced by mountaintop-removal mining frequently have specific conductance (SC), a measure related to the concentration of ions in the water, $30 \times$ greater than unaltered streams (Lindberg et al. 2011, Price et al. 2016, Voss and Bernhardt 2017).

E-mail addresses: ${ }^{4}$ jakemhutton1@gmail.com; ${ }^{5}$ To whom correspondence should be addressed, steven.price@uky.edu; ${ }^{6}$ sbonner6@uwo.ca; ${ }^{7}$ stephen .richter@eku.edu; ${ }^{8}$ barton@uky.edu 
The Central Appalachians harbor one of most biologicallydiverse freshwater assemblages in North America, yet thousands of $\mathrm{km}$ of streams have been affected by valley fills (Bernhardt and Palmer 2011, Bernhardt et al. 2012). Numerous studies have reported severe declines in the abundances and species richness of freshwater taxa in streams affected by mountaintop-removal mining and valley filling (MTR-VF) (Pond et al. 2008, Cormier et al. 2013, Hitt and Chambers 2014, Muncy et al. 2014, Hitt et al. 2016). For example, Hitt and Chambers (2014) found fish abundance, biomass, and diversity were 80,50 , and $49 \%$ lower, respectively, in streams influenced by MTR-VF compared to reference streams. The pathway linking MTR-VF to biotic responses is complex (Palmer et al. 2010, Wickham et al. 2013, Price et al. 2018); however, elevated SC is regularly cited as a driver of distributions, local abundances, and species richness patterns seen in Central Appalachian freshwater taxa (e.g., Pond et al. 2008, Hitt and Chambers 2014). Elevated SC is presumed to reduce or extirpate local populations via osmoregulatory stress and direct mortality (McCulloch et al. 1993, Hassell et al. 2006), increased emigration rates (i.e., downstream drift; Wood and Dykes 2002), or changes in resource subsidies (Hitt and Chambers 2014).

Recent studies have shown that stream salamander species diversity, abundance, and occupancy are reduced in MTR-VF streams compared to reference locations (Wood and Williams 2013, Muncy et al. 2014, Price et al. 2016, 2018). For example, Price et al. (2016) showed that salamander abundances were reduced in MTR-VF streams in southeastern Kentucky, where SC averaged $1780 \mu \mathrm{S} / \mathrm{cm}$ compared to streams unaltered by MTR-VF that averaged $58 \mu \mathrm{S} / \mathrm{cm}$. Thus, elevated SC is considered a major factor of salamander population declines in streams affected by MTR-VF (Schorr et al. 2013, Wood and Williams 2013, Muncy et al. 2014, Price et al. 2016). Amphibians osmoregulate to maintain internal salinity greater than that of the external environment. They expel excess ions cutaneously or via gill filaments to maintain homeostasis when their internal salinity falls below the external environment salinity (Shoemaker and Nagy 1977). Osmoregulation can be energetically costly and may result in adverse effects ranging from increased stress to mortality (Sanzo and Hecnar 2006, Karraker et al. 2008, Chambers 2011). However, previous studies on amphibian response to elevated SC have largely focused on how road salts affect pond-breeding amphibians (Sanzo and Hecnar 2006, Karraker et al. 2008). Investigations are needed to elucidate the relationship between SC and stream salamander populations in streams affected by MTR-VF.

The objective of this study was to examine the association between stream salamander occupancy and abundance and SC in southeastern Kentucky streams. We examined occupancy and abundance of species and life stages along a continuous gradient of SC that ranged from 30 to $1966 \mu \mathrm{S} / \mathrm{cm}$ to test the hypothesis that elevated SC is associated with reductions in salamander populations. We asked the basic question: do stream salamander occupancy rates and abundances decrease as SC increases along a continuous gradient? In addition, we examined correlations between physical and chemical environmental attributes (i.e., forest cover, ion composition) and SC. Specifically, we asked: what is the relationship between individual physical and chemical environmental attributes with SC?

\section{METHODS}

\section{Study sites}

We conducted a field study to characterize ion concentrations and physical and chemical environmental variables of stream reaches in southeastern Kentucky, USA, and to quantify salamander occurrence and abundance along an SC gradient. We sampled salamanders at 30 first-order streams in the Cumberland Plateau in Breathitt, Knott, and Letcher counties in southeastern Kentucky (Fig. 1). Study streams were located on the Main Tract and the Bear Branch Tract of the University of Kentucky's Robinson Forest (RF, Breathitt and Knott counties) as well as Eastern Kentucky University's Lilley Cornett Woods (LCW, Letcher County) and on the Laurel Fork Surface Mine (LFSM, Breathitt County), a reclaimed mine located directly adjacent to RF. We selected stream sites across a continuous gradient of SC values ranging from 30 to $1966 \mu \mathrm{S} / \mathrm{cm}(\mathrm{Ta}-$ ble 1). Ten streams with low SC $(30-70 \mu \mathrm{S} / \mathrm{cm})$ were located in the main block of RF and LCW; see Martin and Shepherd (1973), Martin (1975), and Phillippi and Boebinger (1986) for descriptions of vegetative communities. Ten streams with moderate SC $(101-687 \mu \mathrm{S} / \mathrm{cm})$ were in the Main Tract of RF adjacent to LFSM, the Bear Branch Tract of RF, and the $2^{\text {nd }}$-growth forests adjacent to LCW. These streams had elevated SC values because of surface mining, among other land uses such as timber harvest, in a portion of their catchments (R. Watts [Eastern Kentucky University] and C. Osborne [University of Kentucky], personal communication). Ten streams with high SC (737-1966 $\mathrm{S} / \mathrm{cm})$ were located within the LFSM, a surface mine that was active from the late 1990s to early 2000s and released from bond in November 2007 after reclamation was determined satisfactory.

We delineated $10-\mathrm{m}$ reaches at each stream to sample for stream salamanders. We selected reaches to compare stream salamander capture data to previous studies in the eastern USA (e.g., Grant et al. 2009, Muncy et al. 2014). High-SC stream reaches were in the headwater streams below a valley fill. Low- and moderate-SC stream reaches were selected to contain stream widths, depths, and current velocities similar to those found in the high-SC reaches. All stream reaches contained a pool, a run, and a riffle section to provide habitat likely to increase detections of all possible 


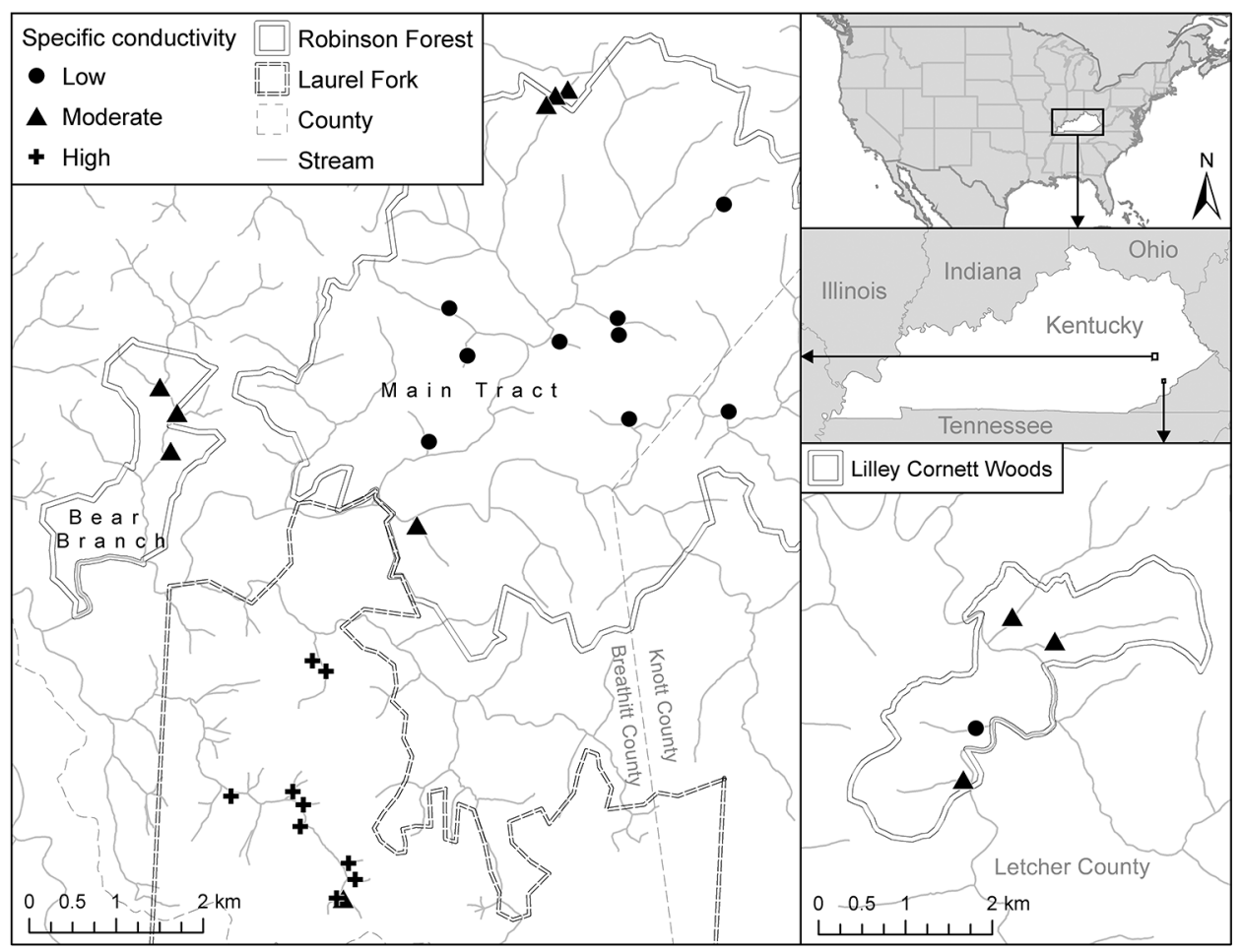

Figure 1. Study area and sampling locations for 30 stream reaches in Breathitt, Knott, and Letcher counties, Kentucky, USA. Streams were located in the University of Kentucky's Robinson Forest (Main Tract and Bear Branch Tract), Eastern Kentucky University's Lilley Cornett Woods, and on the reclaimed Laurel Fork Surface Mine. Symbols represent specific conductivity (SC) category: circles are low-SC streams $(30-70 \mu \mathrm{S} / \mathrm{cm})$, triangles are moderate-SC streams $(101-687 \mu \mathrm{S} / \mathrm{cm})$, and diamonds are high-SC streams $(737-1966 \mu \mathrm{S} / \mathrm{cm})$.

salamander species and life stages. Riparian zones and adjacent terrestrial areas at all study streams were forested. Riparian vegetation composition was similar across the SC gradient because the sampled stream reaches were below the toe of the valley fill, and the riparian vegetation below the fill was relatively undisturbed by the mining process.

\section{Physical environmental attribute sampling}

Prior to conducting salamander counts, we collected 50$\mathrm{mL}$ water samples from the thalweg of each stream. After collection, we immediately placed water samples on ice and later analyzed the samples at the Forestry Hydrology Lab (University of Kentucky, Department of Forestry and Natural Resources) for concentrations of $\mathrm{Ca}^{+2}, \mathrm{Mg}^{+2}, \mathrm{~K}^{+}$, $\mathrm{Na}^{+}, \mathrm{SO}_{4}{ }^{-2}$, total organic carbon (TOC), $\mathrm{pH}$, and SC. We used a GBC SDS 270 Atomic Absorption Spectrophotometer (GBC Scientific Equipment, Melbourne, Australia) to measure $\mathrm{Ca}^{+2}, \mathrm{~K}^{+}, \mathrm{Mg}^{+2}$, and $\mathrm{Na}^{+}$, and we used ion chromatography on a Dionex ${ }^{\mathrm{TM}}$ Ion Chromatograph 2000 (Dionex Corporation, Sunnyvale, California) to measure $\mathrm{SO}_{4}{ }^{-2}$. We used a Shimadzu TOC-Vcsn analyzer (Shimadzu, Kyoto, Japan) to measure TOC concentration. We measured water $\mathrm{pH}$ with a Thermo Scientific ${ }^{\text {TM }}$ Orion Star ${ }^{\text {TM }}$ benchtop $\mathrm{pH}$ meter (model 250A; Thermo Fisher Scientific, Waltham, Massachusetts). We measured SC using a YSI conductivity bridge (model 35; Yellow Springs Incorporated, Yellow Springs, Ohio). We followed all sampling, preservation, and analytic protocols outlined in Greenberg et al. (1992).

We measured several physical environmental attributes at each site to allow for description of stream habitat including water temperature $\left({ }^{\circ} \mathrm{C}\right)$, the number of cover objects (logs $\geq 8 \mathrm{~cm}$ diameter, rocks $\geq 15 \mathrm{~cm}$ diameter), the number of trees within $2 \mathrm{~m}$ of the stream channel within a $10-\mathrm{m}$ transect that were under or over $2 \mathrm{~m}$ tall, and the percentage of detritus in the stream substrate of each transect (as in Pond et al. 2008). We calculated the catchment area (ha) using Hydrology Tools within ArcMap (ArcGIS version 10.4.1; ESRI ${ }^{\circledR}$, Redlands, California). For the base layer for catchment delineation, we used post-mining, highresolution $(0.6 \mathrm{~m})$, digital elevation model data (Muncy et al. 2014). We overlaid the United States Geological Survey 2013 7.5-min image map for the Noble, Kentucky quadrangle (https://www.usgs.gov/core-science-systems/ngp /tnm-delivery/topographic-maps) on stream catchments to calculate the \% catchment in forest cover. We considered both mature and $2^{\text {nd }}$-growth forest classes as forest cover in the analysis of each stream catchment. 
Table 1. Site names, average specific conductivity (SC), elevation, location, catchment size, and \% forest cover for 30 stream study sites in southeastern Kentucky, USA. Streams were located in the University of Kentucky's Robinson Forest (RF; Breathitt and Knott counties), Eastern Kentucky University's Lilley Cornett Woods (LCW; Letcher County) and on the reclaimed the Laurel Fork Surface Mine (LFSM; Breathitt County). SE = standard error.

\begin{tabular}{|c|c|c|c|c|c|}
\hline Site & Location & Elevation (m) & $\mathrm{SC}(\mu \mathrm{S} / \mathrm{cm} \pm \mathrm{SE})$ & Catchment size (ha) & $\%$ forest cover \\
\hline Miller & $\mathrm{RF}$ & 378.26 & $31.53 \pm 2.78$ & 7.98 & 98.75 \\
\hline Falling Rock B & $\mathrm{RF}$ & 327.36 & $36.18 \pm 6.05$ & 17.47 & 100.00 \\
\hline Little Millseat A & RF & 331.32 & $38.43 \pm 4.40$ & 14.99 & 100.00 \\
\hline Field Branch A & $\mathrm{RF}$ & 349.00 & $39.63 \pm 11.84$ & 17.28 & 100.00 \\
\hline Falling Rock A & RF & 320.95 & $39.73 \pm 7.48$ & 12.06 & 100.00 \\
\hline Boardinghouse & $\mathrm{RF}$ & 292.00 & $40.83 \pm 4.24$ & 31.13 & 99.04 \\
\hline Bucklick & RF & 278.59 & $43.83 \pm 2.89$ & 15.64 & 100.00 \\
\hline Tome & $\mathrm{RF}$ & 299.31 & $47.70 \pm 8.35$ & 30.08 & 100.00 \\
\hline Cole's Fork A & $\mathrm{RF}$ & 320.04 & $51.60 \pm 9.64$ & 87.27 & 100.00 \\
\hline Big Everidge & $\mathrm{LCW}$ & 339.55 & $69.58 \pm 4.88$ & 55.30 & 100.00 \\
\hline Bear Branch \#3 & $\mathrm{RF}$ & 291.69 & $100.45 \pm 7.86$ & 5.42 & 69.13 \\
\hline Mart Branch & $\mathrm{RF}$ & 270.05 & $108.13 \pm 16.22$ & 67.02 & 98.71 \\
\hline Pole Branch & $\mathrm{LCW}$ & 338.02 & $130.28 \pm 9.34$ & 90.61 & 97.42 \\
\hline Rich Hollow \#2 & $\mathrm{RF}$ & 378.56 & $286.75 \pm 45.15$ & 8.78 & 70.11 \\
\hline Island Branch & $\mathrm{LCW}$ & 379.48 & $417.75 \pm 49.02$ & 143.84 & 95.35 \\
\hline Rich Hollow \#3 & $\mathrm{RF}$ & 348.69 & $418.25 \pm 85.85$ & 12.42 & 100.00 \\
\hline Whitaker Branch & $\mathrm{LCW}$ & 372.47 & $442.00 \pm 92.28$ & 28.14 & 74.15 \\
\hline White Oak Left & LFSM & 347.47 & $480.25 \pm 117.49$ & 10.81 & 49.58 \\
\hline Rich Hollow \#1 & RF & 381.00 & $501.75 \pm 226.04$ & 8.61 & 15.31 \\
\hline Bear Branch \#1 & $\mathrm{RF}$ & 287.43 & $552.50 \pm 91.23$ & 3.33 & 90.82 \\
\hline Bear Branch \#2 & $\mathrm{RF}$ & 269.44 & $686.75 \pm 99.37$ & 4.37 & 68.29 \\
\hline Turkey & LFSM & 292.91 & $736.75 \pm 122.60$ & 6.89 & 78.21 \\
\hline Bee Branch Near & LFSM & 322.78 & $1286.50 \pm 175.53$ & 37.17 & 35.59 \\
\hline White Oak Right & LFSM & 337.41 & $1382.25 \pm 99.68$ & 32.03 & 44.19 \\
\hline Bee Branch Far & LFSM & 279.20 & $1409.50 \pm 167.76$ & 22.47 & 29.60 \\
\hline White Oak & LFSM & 339.24 & $1439.50 \pm 175.19$ & 24.50 & 40.59 \\
\hline Stillrock & LFSM & 344.12 & $1549.50 \pm 272.03$ & 12.69 & 46.31 \\
\hline Big Hollow & LFSM & 317.00 & $1609.00 \pm 112.83$ & 18.74 & 23.41 \\
\hline Wharton & LFSM & 331.62 & $1954.75 \pm 195.94$ & 61.53 & 21.66 \\
\hline Hickory Log & LFSM & 303.28 & $1965.50 \pm 192.81$ & 13.88 & 45.16 \\
\hline
\end{tabular}

\section{Physical and chemical environmental attributes analysis}

We constructed scatterplots and computed correlations to examine associations between the physical and chemical attributes of the sites. Our analysis focused primarily on the relationship between these attributes and SC. We transformed several of the attributes either with the logarithmic or logit transformation in order to achieve linearity with SC so that the correlation would be representative of the strength of each relationship. We also found that the chemical attributes were best correlated with the logarithm of SC. We conducted the analysis in 2 ways: 1) we computed the correlations among $\mathrm{SC}$ (on the natural scale) and the physical attributes (catchment size, elevation, $\%$ detritus, elevation, $\%$ forest cover, number of logs, num- ber of rocks, water temperature, and trees under or over $2 \mathrm{~m}$ tall); and 2) we computed the correlations among the logarithm of SC and the chemical attributes $\left(\mathrm{Ca}^{+2}, \mathrm{~K}^{+}\right.$, $\mathrm{Mg}^{+2}, \mathrm{Na}^{+}, \mathrm{SO}_{4}{ }^{-2}, \mathrm{pH}$, and TOC).

\section{Salamander sampling}

We counted salamanders in each $10-\mathrm{m}$ reach $4 \times$ (every 22 d) from April to July 2017 during daylight hours (0800-1700) and in baseflow conditions. Prior to sampling we recorded the number of days since last rain and the day of year because these factors may influence our ability to detect salamanders (Price et al. 2012). We used systematic dipnetting and bank searches to capture salamanders (Price et al. 2012). Dipnetting consisted of 1 person moving 
from downstream to upstream and using a dipnet to capture salamanders around and under submerged rocks, logs, and other cover within the 10-m reach. After dipnetting, the same person conducted bank searches, which included searching under rocks, logs, leaf litter, and other material within $1 \mathrm{~m}$ of the wetted width of the stream. Stream searches were limited to $0.5 \mathrm{~h}$ and bank searches to $0.25 \mathrm{~h}$ (Price et al. 2012). We temporarily removed the salamanders from the stream reaches and banks during sampling and counted the number of individuals. We then recorded the species and life stage (larval or adult) of each salamander. Processing of salamanders generally lasted 30 to $60 \mathrm{~min}$, depending on the number of animals we captured at a site. We released salamanders within the sampled stream reach after data recording. In addition to captured salamanders, we recorded data for salamanders that were visually detected and identified but that evaded capture. We sampled from downstream to upstream, reducing the likelihood of recounting salamanders because they generally do not move towards disturbance and typically move to retreats near the point of capture.

\section{Occupancy and abundance analysis}

We separated salamander count data by species and life stage for occupancy and abundance analyses. We detected 9 salamander species during dipnetting and bank searches: Allegheny Dusky Salamander (Desmognathus ochrophaeus; Cope 1859), Black Mountain Salamander (Desmognathus welteri; Barbour 1950), Northern Dusky Salamander (Desmognathus fuscus; Rafinesque 1820), Seal Salamander (Desmognathus monticola; Dunn 1916), Spring Salamander (Gyrinophilus porphyriticus; Green 1827), Red Salamander (Pseudotriton ruber; Sonnini and Latreille 1801), Longtail Salamander (Eurycea longicauda; Green 1818), Southern Two-lined Salamander (Eurycea cirrigera; Green 1831), and Southern Ravine Salamander (Plethodon richmondi; Netting and Mittleman 1938). However, we only considered 5 species (D. fuscus, D. monticola, G. porphyriticus, P. ruber, and $E$. cirrigera) in our analysis, because these species are primarily associated with streams and were captured in sufficient numbers to allow statistical analyses. We then assigned the salamanders to 8 groups based on species and life stage: adult $D$. fuscus, $D$. monticola, and E. cirrigera and larval $D$. fuscus, D. monticola, E. cirrigera, G. porphyriticus, and P. ruber. Adults of G. porphyriticus and P. ruber captures were combined with their larvae because their counts were low $(n=2)$.

We used a hierarchical Bayesian modeling approach to estimate species-specific and life-stage-specific responses to SC. This method fits a N-mixture model to each species with a prior that relates the different parameters across species, where $O_{i j}$ denotes whether species $i$ is present at site $j, N_{i j}$ denotes the abundance of species $i$ at site $j$, and $n_{i j k}$ denotes the number of individuals of species $i$ counted at site $j$ on visit $k$ (Dorazio et al. 2013). The model assumes that $O_{i j}\left|\psi_{i j} \sim \operatorname{Bernoulli}\left(\psi_{i j}\right), N_{i j}\right| O_{i j}>0, \lambda_{i} \sim \operatorname{ZTPoisson}\left(\lambda_{i j}\right)$, and $n_{i j k} \mid N_{i j} p_{i} \sim \operatorname{Binomial}\left(N_{i j} p_{i}\right)$, where $\psi_{i}, \lambda_{i}$, and $p_{i}$ represent the occupancy probability, mean abundance/occupied site, and individual detection probability for species $i$, respectively. The distribution of $N_{i j}$ is assumed to be a 0 truncated Poisson if $O_{i j}=1$, and $N_{i j}$ is fixed to be 0 if $O_{i j}=0$ (i.e., an occupied site must have at least 1 individual present, and an unoccupied site must have no individuals present). We further modeled the occupancy and abundance parameters dependent on the mean observed $\mathrm{SC}$ at site $j$ as $\operatorname{logit}\left(\psi_{i j}\right)=\beta_{0 i}+\beta_{1 i}$ Conductivity $_{j}$ and $\log \left(\lambda_{i j}\right)=\gamma_{0 i}+\gamma_{1 i}$ Conductivity $y_{j}$. We modeled the detection probability on the logistic scale as $\operatorname{logit}\left(p_{i j k}\right)=\delta_{0 i}+$ $\delta_{1 i}$ Days Since Last Rain ${ }_{j k}+\delta_{2 i}$ Day of Year $_{j k}$. This approach allowed the detection probability to vary by species and also allowed for species-specific effects of the number of days since last rain and the day of year. We then assigned regression parameters hierarchical priors such that $\beta_{0 i} \sim$ Normal $\left(\mu_{\beta 0}, \tau_{\beta 0}^{2}\right)$ and $\beta_{1 i} \sim \operatorname{Normal}\left(\mu_{\beta 1}, \tau_{\beta 1}^{2}\right)$. We used a similar approach for $\gamma_{0 i}, \gamma_{1 i} ; \delta_{0 i}, \delta_{1 i}$; and $\delta_{2 i}$. These priors relate the parameters across the species, but the data determined the strength of the relationship.

We used the software JAGS (version 4.3.0; Plummer 2003) to fit the models with Markov chain Monte Carlo sampling. Specifically, we ran the sampler with 3 chains started at diffuse initial values. Each chain was run for 5000 iterations burn-in and 100,000 sampling iterations. Convergence was assessed with the Brooks-Gelman-Rubin diagnostics (Gelman and Rubin 1992). We found no evidence for lack of convergence. That is, point estimates of the potential scale reduction factors were $<1.01$ for all of the speciesspecific parameters and $<1.04$ for all hyperparameters. We approximated posterior summary statistics, including the mean, standard deviation, and credible intervals (CI; 95\%), for each of the model parameters as well as derived quantities including occupancy probability and abundance for each species or life stage.

\section{RESULTS}

\section{Physical and chemical environmental attributes}

Most physical environmental attributes showed a weak relationship with SC (Table 2, Fig. S1). However, we found evidence that \% detritus in the stream substrate in each transect was positively correlated with $\mathrm{SC}(r=0.53)$. Forest cover within the stream catchment $(r=-0.81)$ and the number of rocks in the stream substrate $(r=-0.66)$ were negatively correlated with SC. We found moderately-strong correlations among physical environmental variables, including a decrease in the number of rocks with \% detritus in each transect $(r=-0.46)$ (see Table 2 and Fig. S1 for full details).

We found evidence that several chemical environmental attributes were strongly-positively correlated with the 
Table 2. Correlations among physical environmental attributes measured in streams in southeastern Kentucky, USA. Attributes denoted with * have been log transformed prior to computing the correlation. \% forest cover was bounded between 1 and 99 and logit transformed prior to correlation.

\begin{tabular}{|c|c|c|c|c|c|c|c|c|c|}
\hline Attribute & $\begin{array}{l}\text { Catchment } \\
\text { size }\end{array}$ & $\%$ Detritus* & Elevation & $\begin{array}{l}\% \text { forest } \\
\text { cover }\end{array}$ & $\begin{array}{c}\text { Number } \\
\text { of logs }\end{array}$ & $\begin{array}{l}\text { Number } \\
\text { of rocks"* }\end{array}$ & $\begin{array}{l}\text { Water } \\
\text { temp }\end{array}$ & $\begin{array}{l}\text { Number of } \\
\text { trees }<2 \mathrm{~m}\end{array}$ & $\begin{array}{l}\text { Number of } \\
\text { trees }>2 \mathrm{~m}\end{array}$ \\
\hline Specific conductivity & 0.02 & 0.53 & -0.06 & -0.81 & 0.03 & -0.66 & 0.10 & 0.34 & -0.06 \\
\hline Catchment size* & & -0.29 & 0.15 & 0.20 & 0.24 & 0.07 & 0.04 & -0.25 & -0.19 \\
\hline$\%$ detritus" & & & -0.05 & -0.43 & 0.37 & -0.46 & -0.30 & 0.32 & 0.14 \\
\hline Elevation & & & & -0.08 & -0.04 & 0.13 & 0.27 & 0.21 & 0.05 \\
\hline$\%$ forest cover & & & & & 0.02 & 0.43 & -0.19 & -0.23 & -0.11 \\
\hline Number of logs & & & & & & -0.05 & -0.47 & -0.24 & 0.34 \\
\hline Number of rocks* & & & & & & & 0.09 & -0.26 & 0.05 \\
\hline Water temperature & & & & & & & & 0.17 & 0.01 \\
\hline Number of trees $<2 \mathrm{~m}$ & & & & & & & & & 0.07 \\
\hline
\end{tabular}

logarithm of SC (Table 3, Fig. S2). Concentrations of dissolved ions $\mathrm{SO}_{4}{ }^{-2}, \mathrm{Ca}^{+2}, \mathrm{Mg}^{+2}, \mathrm{~K}^{+}$, and $\mathrm{Na}^{+}$were positively correlated with the logarithm of the $\mathrm{SC}(r \geq 0.76$ for all ions; see Table 3), and $\mathrm{pH}$ was weakly but positively correlated with the logarithm of SC $(r=0.24)$. We also found that correlations among chemical environmental variables were strong in some cases (see Table 3 and Fig. S2 for full details).

\section{Salamander occupancy and abundance}

In total we counted 2319 salamanders across the study: 657 adults and 1662 larvae. Specifically, we counted $280 D$. fuscus adults, $284 \mathrm{D}$. monticola adults, 89 E. cirrigera adults, 191 D. fuscus larvae, 205 D. monticola larvae, 1015 E. cirrigera larvae, $183 \mathrm{G}$. porphyriticus (combined adults and larvae), and 72 P. ruber (combined adults and larvae). We found a general decline in occupancy probabilities of all salamander groups as SC increased (Fig. 2). For example, the estimated occupancy probability of $D$. fuscus adults at 250 $\mu \mathrm{S} / \mathrm{cm}$ was 0.95 (95\% CI $=0.89,0.98)$, but it decreased to $0.23(95 \% \mathrm{CI}=0.05,0.52)$ at $2000 \mu \mathrm{S} / \mathrm{cm}$. Furthermore, posterior means and $95 \% \mathrm{CI}$ for the parameters modeling the effect of SC on occupancy $\left(\beta_{1 j}\right)$ were negative for all sal- amander groups (Fig. 3A, Table 4). Thus, when all salamanders were considered together, the mean response to increasing SC was negative $\left(\mu_{\beta 1}=-0.24 ; 95 \% \mathrm{CI}=-0.33\right.$, $-0.15)$, indicating that salamanders, as a group, occurred less frequently at elevated SC levels (Fig. 3A, Table 5). Furthermore, the model indicated that the response was similar across all species and life stages, which is indicated by the very small point estimates for the posterior variance of the regression coefficients modeling the effects of SC on occupancy and by the $95 \%$ CI for these parameters, which have a lower bound of 0 . This result suggests that the response may be very close to constant across species (Table 6).

For 5 groups, we also found that mean salamander abundance given occupancy declined as SC increased (Fig. 4). For example, the estimated abundance of larval E. cirrigera decreased from $63.38(44.92-92.33) \mathrm{ind} / 10 \mathrm{~m}$ at $250 \mu \mathrm{S} / \mathrm{cm}$ to $0.38(0.04-1.04) \mathrm{ind} / 10 \mathrm{~m}$ at $2000 \mu \mathrm{S} / \mathrm{cm}$. However, we found no significant effect of SC on the abundances of larval $D$. fuscus, larval $P$. ruber, or adult E. cirrigera for which the $95 \%$ CI of posterior means overlapped 0 (Fig. 3B, Table 4). Nonetheless, when all salamander species were considered together, the mean response to $\mathrm{SC}$ was negative $\left(\mu_{\gamma 1}=-0.09 ; 95 \% \mathrm{CI}=-0.16,-0.002\right)$, suggesting that

Table 3. Correlations between chemical environmental attributes measured in streams in southeastern Kentucky, USA. Attributes denoted with * have been log transformed prior to computing the correlation. Specific conductivity was log transformed prior to analyses. $\mathrm{TOC}=$ total organic carbon.

\begin{tabular}{lcccccrr}
\hline Attribute & Calcium & Potassium* $^{*}$ & Magnesium & Sodium* & pH & Sulfate $^{*}$ & TOC $^{*}$ \\
\hline Specific conductivity & 0.99 & 0.97 & 0.99 & 0.92 & 0.24 & 0.76 & 0.07 \\
Calcium & & 0.97 & 0.99 & 0.91 & 0.28 & 0.73 & 0.09 \\
Potassium & & & 0.99 & 0.87 & 0.37 & 0.69 & 0.23 \\
Magnesium & & & 0.87 & 0.29 & 0.71 & 0.11 \\
Sodium & & & & 0.27 & 0.78 & 0.02 \\
Sulfate & & & & & & 0.09 & 0.59 \\
pH & & & & & & & -0.11 \\
\hline
\end{tabular}




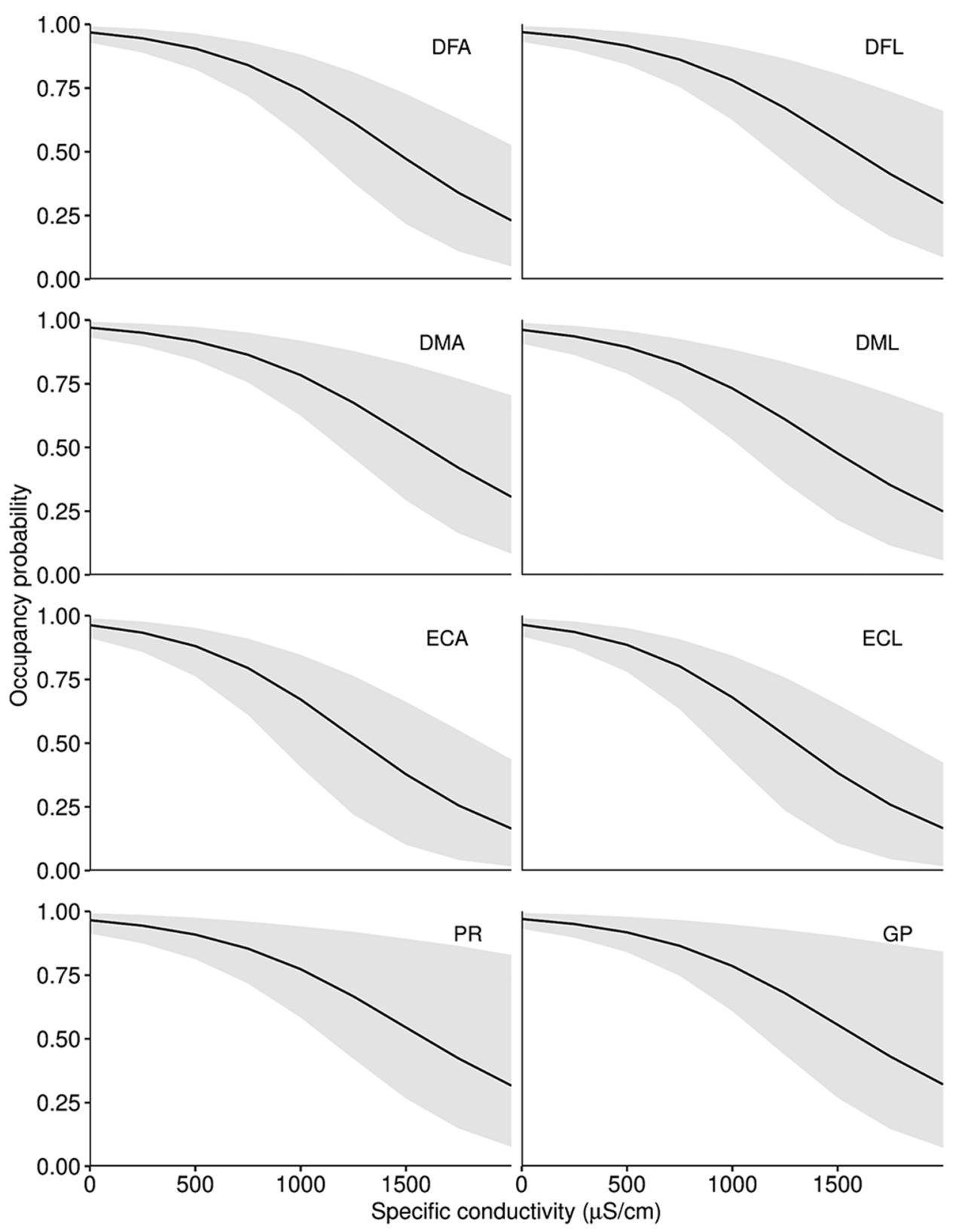

Figure 2. Mean estimated occupancy probabilities (solid black line) with pointwise 95\% credible intervals (shaded gray region) for salamanders detected at stream reaches along a continuous specific conductivity gradient in southeastern Kentucky, USA. Groups are denoted as Desmognathus fuscus adults and larvae (DFA, DFL), Desmognathus monticola adults and larvae (DMA, DML), Eurycea cirrigera adults and larvae (ECA, ECL), Gyrinophilus porphyriticus (GP), and Pseudotriton ruber (PR). We combined G. porphyriticus and $P$. ruber adults and larvae because adult counts were low $(n=2)$ for these species.

salamanders, as a group, are less abundant given occupancy at elevated SC levels (Fig. 3B, Table 5). Additionally, the association between SC and salamanders was similar across all species and life stages as indicated by the small posterior variance parameters of the regression coefficients modeling the effects of SC on abundance (Table 6).

The effects of sampling covariates (i.e., days since last rain and day of year) on detection probabilities varied among species and life stages (Fig. 5A, B). Most species and life stages were more detectable as day of last rain increased. In fact, when we considered all salamander groups together, we found that as day since last rain increased, detection probability increased $\left(\delta_{1 i}=0.09 ; 95 \% \mathrm{CI}=0.03,0.14\right)$. Adult and larval $D$. fuscus and $G$. porphyriticus and adult E. cirrigera had higher detection probabilities during sampling at earlier dates, whereas larval D. monticola, larval E. cirrigera, and 


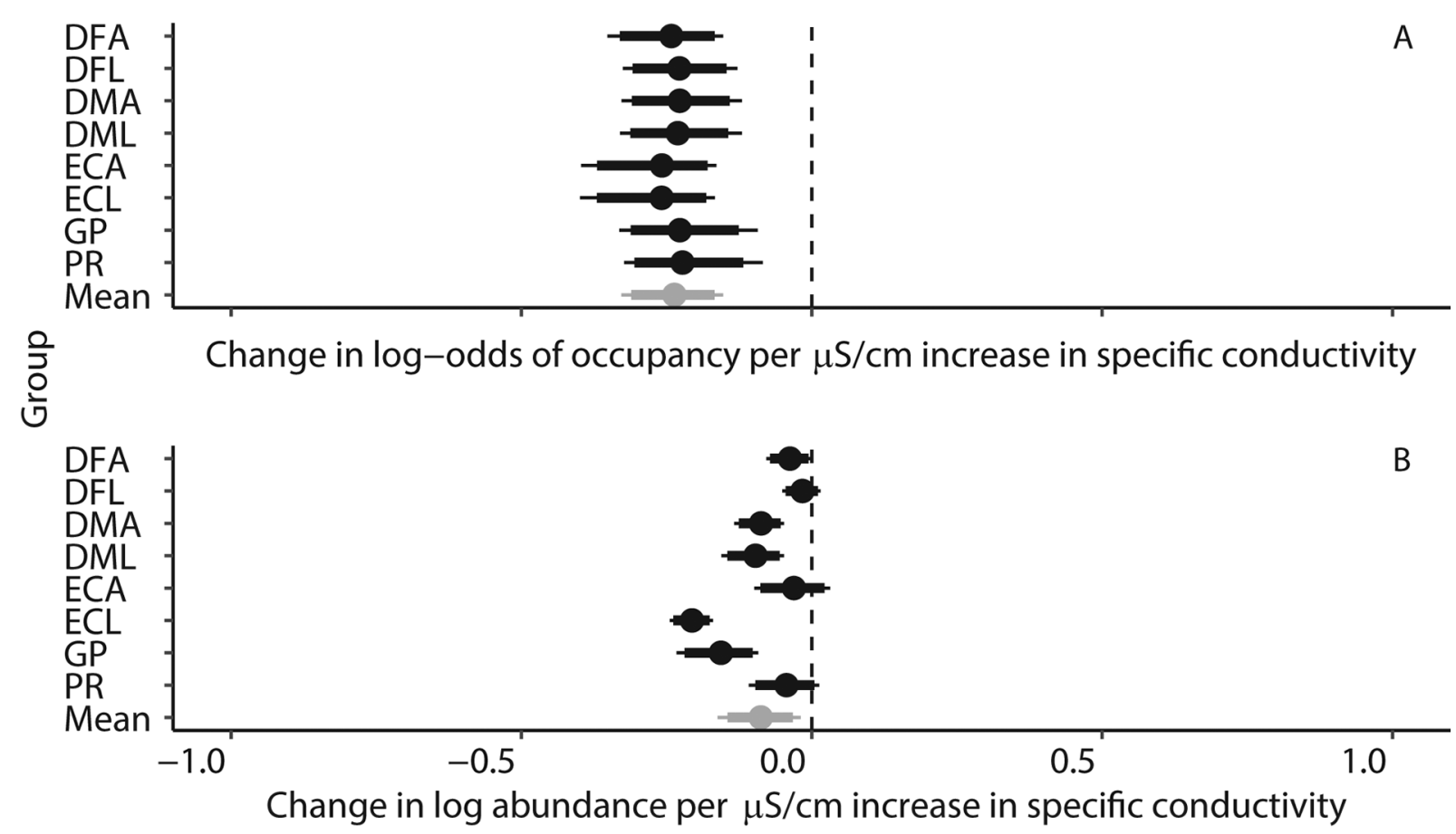

Figure 3. Salamander group estimates of occupancy probability (A) and mean abundance (B) across a continuous specific conductivity gradient in southeastern Kentucky, USA. The points represent posterior means, the wide bands represent the central $50 \%$ credible interval, and the thin bands represent the central 95\% credible interval. Groups are denoted as Desmognathus fuscus adults and larvae (DFA, DFL), Desmognathus monticola adults and larvae (DMA, DML), Eurycea cirrigera adults and larvae (ECA, ECL), Gyrinophilus porphyriticus (GP), and Pseudotriton ruber (PR). We combined G. porphyriticus and P. ruber adults and larvae because adult counts were low $(n=2)$ for these species.

Table 4. Mean and 95\% credible intervals for occupancy $(\beta 0, \beta 1)$, abundance $(\gamma 0, \gamma 1)$, and detection $(\delta 0, \delta 1, \delta 2)$ parameters across salamander species and life stages in relation to specific conductivity. Specifically, $\beta_{1 i}$ and $\gamma_{1 i}$ (where $i$ indicates species) are the effect of conductivity on salamander occupancy and abundance, respectively. Detection parameters included number of days since last rain $\left(\delta_{1}\right)$ and day of year $\left(\delta_{2}\right)$.

\begin{tabular}{|c|c|c|c|c|}
\hline \multirow[b]{2}{*}{ Parameters } & \multicolumn{2}{|c|}{ Desmognathus fuscus } & \multicolumn{2}{|c|}{ Desmognathus monticola } \\
\hline & Adult & Larva & Adult & Larva \\
\hline$\beta_{0}$ & $3.56(2.56,4.79)$ & $3.61(2.60,4.90)$ & $3.62(2.61,4.93)$ & $3.35(2.29,4.44)$ \\
\hline$\beta_{1}$ & $-0.24(-0.35,-0.15)$ & $-0.23(-0.33,-0.13)$ & $-0.23(-0.33,-0.13)$ & $-0.23(-0.33,-0.12)$ \\
\hline$\gamma_{0}$ & $2.32(1.97,2.71)$ & $3.01(2.34,4.04)$ & $2.50(2.16,2.90)$ & $2.70(2.25,3.27)$ \\
\hline$\gamma_{1}$ & $-0.04(-0.08,0.00)$ & $-0.02(-0.05,0.02)$ & $-0.09(-0.13,-0.05)$ & $-0.10(-0.16,-0.05)$ \\
\hline$\delta_{0}$ & $-0.43(-1.09,0.18)$ & $-1.91(-3.07,-1.07)$ & $-0.97(-1.54,-0.45)$ & $-2.50(-3.14,-1.96)$ \\
\hline$\delta_{1}$ & $0.12(0.06,0.20)$ & $0.12(0.06,0.20)$ & $0.09(0.02,0.16)$ & $0.11(0.04,0.18)$ \\
\hline \multirow[t]{3}{*}{$\delta_{2}$} & $-0.14(-0.20,-0.08)$ & $-0.14(-0.20,-0.09)$ & $-0.01(-0.06,-0.04)$ & $0.17(0.11,0.24)$ \\
\hline & \multicolumn{2}{|c|}{ Eurycea cirrigera } & Gyrinophilus porphyriticus & Pseudotriton ruber \\
\hline & Adult & Larva & Adults and larva & Adults and larva \\
\hline$\beta 0$ & $3.40(2.35,4.56)$ & $3.44(2.45,4.61)$ & $3.65(2.62,5.11)$ & $3.50(2.36,4.91)$ \\
\hline$\beta 1$ & $-0.26(-0.40,-0.17)$ & $-0.27(-0.40,-0.17)$ & $-0.22(-0.33,-0.10)$ & $-0.22(-0.32,-0.08)$ \\
\hline$\gamma 0$ & $2.49(1.51,3.78)$ & $4.71(4.39,5.10)$ & $2.73(2.15,3.54)$ & $2.53(1.56,3.80)$ \\
\hline$\gamma 1$ & $-0.03(-0.10,0.03)$ & $-0.21(-0.25,-0.17)$ & $-0.16(-0.23,-0.09)$ & $-0.04(-0.11,0.01)$ \\
\hline$\delta 0$ & $-1.34(-2.90,0.10)$ & $-3.05(-3.46,-2.70)$ & $-1.32(-2.27,-0.55)$ & $-3.45(-4.84,-2.34)$ \\
\hline$\delta 1$ & $0.07(-0.04,0.15)$ & $0.10(0.06,0.14)$ & $0.03(-0.09,0.12)$ & $0.08(-0.02,0.16)$ \\
\hline$\delta 2$ & $-0.30(-0.42,-0.20)$ & $0.21(0.18,0.24)$ & $-0.06(-0.12,-0.01)$ & $0.13(0.04,0.23)$ \\
\hline
\end{tabular}


Table 5. Posterior summaries for hierarchical mean parameters (and 95\% credible interval) for occupancy $\left(\mu_{\beta 0}, \mu_{\beta 1}\right)$, abundance $\left(\mu_{\gamma 0}, \mu_{\gamma 1}\right)$, and detection $\left(\mu_{\delta 0}, \mu_{\delta 1}, \mu_{\delta 2}\right)$. The means represent the average values of their respective parameters across all salamander species and life stages in the study.

\begin{tabular}{lc}
\hline Parameter & Mean estimate $(95 \%$ credible interval) \\
\hline$\mu_{\beta 0}$ & $3.47(2.61,4.47)$ \\
$\mu_{\beta 1}$ & $-0.24(-0.33,-0.15)$ \\
$\mu_{\gamma 0}$ & $2.75(1.90,3.52)$ \\
$\mu_{\gamma 1}$ & $-0.09(-0.16,-0.02)$ \\
$\mu_{\delta 0}$ & $-1.75(-2.65,-0.78)$ \\
$\mu_{\delta 1}$ & $0.09(0.03,0.14)$ \\
$\mu_{\delta 2}$ & $-0.03(-0.19,0.14)$ \\
\hline
\end{tabular}

adult and larval $P$. ruber had higher detection probabilities during sampling at later dates (Fig. 5A, B, Table 4).

\section{DISCUSSION}

Stream salamander populations are known to be reduced in streams affected by MTR-VF (e.g., Wood and Williams 2013, Muncy et al. 2014, Price et al. 2016), yet few studies have examined the response of these populations to specific stressors associated with MTR-VF including elevated SC. We investigated the association between SC and stream salamander populations by conducting salamander counts in 30 southeastern Kentucky streams across a continuous gradient of SC. We also assessed correlations between physical and chemical environmental attributes and SC. We found that salamander occupancy decreased as $\mathrm{SC}$ increased across all species and life stages. Furthermore, abundance given occupancy of most species and life stages decreased as SC increased. We found a positive correlation between SC and \% detritus and a negative correlation between SC and the number of rocks in the stream as well as $\mathrm{SC}$ and \% forest cover in the stream catchment. In addition, $\mathrm{SO}_{4}{ }^{-2}, \mathrm{Ca}^{+2}, \mathrm{Mg}^{+2}, \mathrm{~K}^{+}$, and $\mathrm{Na}^{+}$were positively correlated with SC. Thus, a limitation of our study is the inability to tease apart the potential effects of physical and chemical environmental attributes from the effects of SC on patterns of stream salamander occupancy and abundance. Furthermore, our results cannot identify causal factors, such as specific ions, potentially responsible for reduced salamander populations in sites with elevated SC.

We found that occupancy and abundance of most species and life stages decreased as SC increased. Our results support previous research findings on associations between salamanders and SC. Miller et al. (2007) found that larval $E$. cirrigera abundance was negatively related to SC in urban streams, and Schorr et al. (2013) found that the occurrences of 4 salamander species in southeastern Tennessee were negatively correlated with elevated SC. In addition, our findings complement previous studies of streams affected by MTR-VF mining that found declines in occurrence, abundance, or species richness of fish and macroinvertebrates as SC increased along a continuous gradient (Cormier et al. 2013, Hitt and Chambers 2014, Hitt et al. 2016).

Reduced occupancy and abundance of stream salamanders at the study sites may be caused by osmoregulatory stress and reductions to survivorship. Chambers (2011) found that increased SC led to elevated corticosterone levels and altered activity and feeding behaviors in larval Jefferson Salamanders (Ambystoma jeffersonianum; Green 1827). In addition, studies in saline environments, specifically those contaminated with road salt, have shown significant reductions in embryonic and larval survival of Spotted Salamanders (Ambystoma maculatum; Shaw 1802) and Wood Frogs (Lithobates sylvaticus; LeConte 1825) (Sanzo and Hecnar 2006, Karraker et al. 2008). Furthermore, elevated SC $(>250 \mu \mathrm{S} / \mathrm{cm})$ has been linked to malformations in developing amphibian larvae (Sanzo and Hecnar 2006). However, previous studies on the response of amphibians to elevated SC have largely focused on pond-breeding amphibians and road salts. Our research fills an important gap by examining the responses of stream salamanders to elevated SC. Future research is needed on amphibian physiological responses to component ions typical of streams draining MTR-VF landscapes as well as the combined toxicity of solutes.

A reduction of prey populations may explain the decreased occupancy and abundance of stream salamanders along the SC gradient in our study. Elevated SC is known to reduce the abundance, biomass, and diversity of aquatic macroinvertebrates (Kennedy et al. 2003, Hartman et al. 2005, Pond et al. 2008, Pond 2010, 2012, Merriam et al. 2011, Cormier et al. 2013), which dietary studies have reported are a major component of the stomach contents of larval stream salamanders. Macroinvertebrates consumed by larval stream salamanders are primarily larvae from the orders Ephemeroptera, Plecoptera, Trichoptera, and Diptera (Martof and Scott 1957, Caldwell and Houtcooper

Table 6. Posterior summaries for hierarchical variance parameters (and 95\% credible interval) for occupancy $\left(\sigma_{\beta 0}, \sigma_{\beta 1}\right)$, abundance $\left(\sigma_{\gamma 0}, \sigma_{\gamma 1}\right)$, and detection $\left(\sigma_{\delta 0}, \sigma_{\delta 1}, \sigma_{\delta 2}\right)$. The variance parameters represent the variation in salamander species and life stages. Parameters with smaller variance parameters are more similar across all salamander species and life stages, whereas those with larger variance parameters are less similar.

\begin{tabular}{lc}
\hline Parameter & Mean estimate $(95 \%$ credible interval) \\
\hline$\sigma_{\beta 0}$ & $0.39(0.01,1.29)$ \\
$\sigma_{\beta 1}$ & $0.04(0.00,0.15)$ \\
$\sigma_{\gamma 0}$ & $1.02(0.56,1.89)$ \\
$\sigma_{\gamma 1}$ & $0.09(0.05,0.18)$ \\
$\sigma_{\delta 0}$ & $1.33(0.70,2.39)$ \\
$\sigma_{\delta 1}$ & $0.05(0.00,0.14)$ \\
$\sigma_{\delta 2}$ & $0.22(0.12,0.42)$ \\
\hline
\end{tabular}



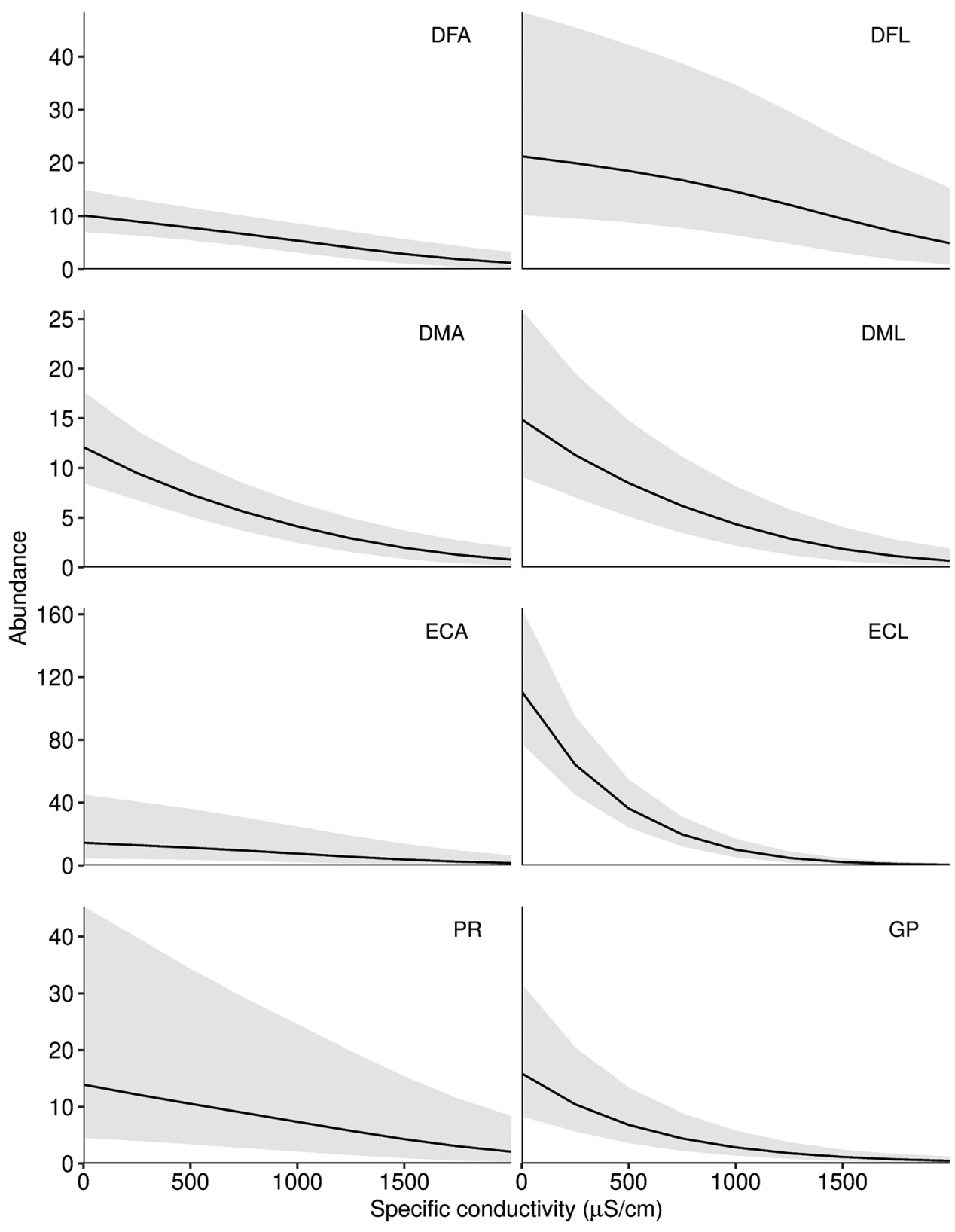

Figure 4. Estimated mean abundances (solid black line) with pointwise 95\% credible intervals (shaded gray region) for salamanders detected at stream reaches along a continuous specific conductivity gradient in southeastern Kentucky, USA. Groups are denoted as Desmognathus fuscus adults and larvae (DFA, DFL), Desmognathus monticola adults and larvae (DMA, DML), Eurycea cirrigera adults and larvae (ECA, ECL), Gyrinophilus porphyriticus (GP), and Pseudotriton ruber (PR). We combined G. porphyriticus and P. ruber adults and larvae because adult counts were low $(n=2)$ for these species.

1973, Davic 1991, Brophy and Pauley 1997, Cecala et al. 2007, Hutton et al. 2018). These orders show decreased abundance and richness in streams with elevated SC (Pond et al. 2008, Cormier et al. 2013). It is not unprecedented for declining prey populations to affect higher trophic levels. For example, Johnson and Wallace (2005) indicated that a reduction in prey populations may decrease growth and body condition in larval salamanders. In addition, Kraus et al. (2016) reported that trout alter their foraging behaviors and consume sub-optimal terrestrial prey in streams af- fected by mining activity. Furthermore, declines in abundance of some fish species in streams with elevated SC appear to be linked to decreased availability of aquatic macroinvertebrate prey (Hitt and Chambers 2014). Although we did not measure the macroinvertebrate assemblage, our data suggest that density of certain macroinvertebrates may be reduced. For example, we found a positive correlation between SC and \% detritus (Table 2), which previous studies have linked to decreases in macroinvertebrate shredder density and diversity (Fritz et al. 2010). Thus, reductions 


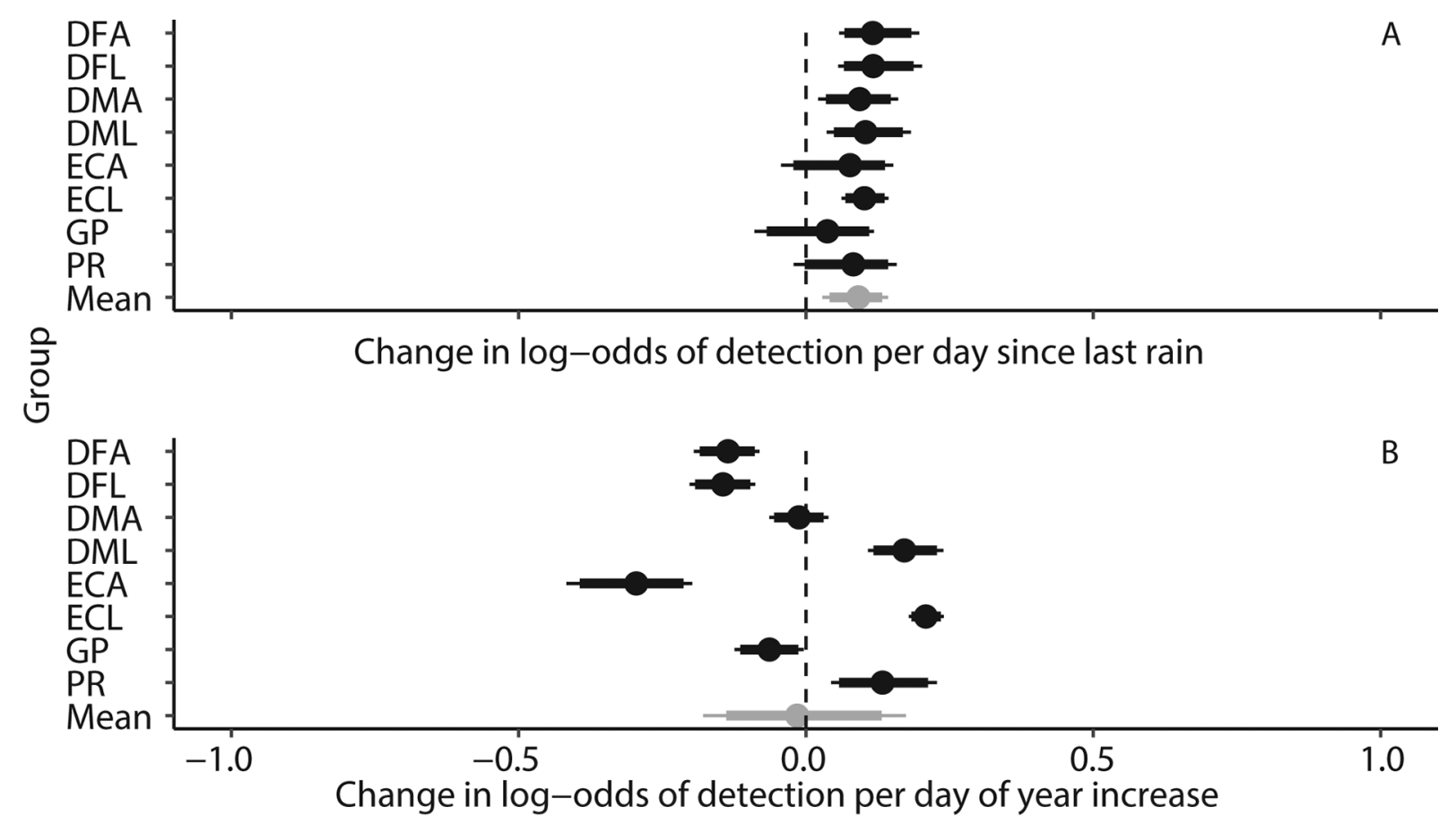

Figure 5. Model estimated detection parameters of last day of rain (A) and day of the year (B) for salamanders observed at stream reaches along a continuous specific conductivity gradient in southeastern Kentucky, USA. The points represent posterior means, the wide bands represent the central 50\% credible interval, and the thin bands represent the central 95\% credible interval. Groups are denoted as Desmognathus fuscus adults and larvae (DFA, DFL), Desmognathus monticola adults and larvae (DMA, DML), Eurycea cirrigera adults and larvae (ECA, ECL), Gyrinophilus porphyriticus (GP), and Pseudotriton ruber (PR). We combined G. porphyriticus and $P$. ruber adults and larvae because adult counts were low $(n=2)$ for these species.

in salamander prey, such as shredders, may be a possible mechanism leading to reduced occupancy and abundances of salamanders in streams with elevated SC. To examine this potential mechanism, future research should focus on how macroinvertebrate diversity and density, as well as salamander diet, change in relation to SC.

We found evidence that several physical and chemical environmental attributes were correlated with SC, which suggests that SC may be one of many factors associated with patterns of salamander occupancy and abundance in Central Appalachian streams. For example, forest cover within the stream catchments was strongly-negatively correlated with SC. Forest loss from logging, agriculture, or urban development can lead to population decline in some stream salamander species (e.g., Barrett et al. 2010, Price et al. 2011, Grant et al. 2016). Consequences of forest loss for stream salamanders include changes to base flow conditions in streams and warmer and drier conditions in forests adjacent to streams, which reduces the quality of terrestrial microhabitats and may inhibit population processes (e.g., Price et al. 2018). Reductions in forest cover near streams also alter in-stream habitat conditions, such as substrate composition (Lowe et al. 2004, Barrett et al. 2010). Indeed, we found a negative correlation between the number of rocks within our sampling reach and SC. Fewer rocks within streams with elevated SC is likely caused by the higher proportion of fine sediment in streams affected by MTR-VF. Rocks may become buried in sediment in these streams, which results in poor habitat for salamanders and can lead to reduced abundances (Lowe et al. 2004).

We note the difficulty of teasing apart the effects of SC on aquatic biota from the effects of other physical environmental attributes, an observation which has been similarly made by others (Pond et al. 2008, Hitt and Chambers 2014). However, we argue that elevated SC is an important driver of salamander occupancy and abundances in the study area. Our argument is based on the fact that stream salamander species and life stages typically exhibit differential responses to physical environmental attributes, such as forest cover and sedimentation, because of variations in larval period, larval body size, and terrestrial habitat use by adults (Price et al. 2011, Gould et al. 2017, Cecala et al. 2018). For example, Cecala et al. (2018) found that occupancy of Blue Ridge Two-lined Salamander (Eurycea wilderae; Dunn 1920) larvae was not positively associated with forest cover, whereas occupancy of Black-bellied Salamanders (Desmognathus quadramaculatus; Holbrook 1840) was strongly predicted by forest cover within stream catchments. Similarly, previous studies have shown that species often respond differently to alterations of in-stream habitat, with some species (e.g., Eurycea spp.) being tolerant of sedimentation (Keitzer and Goforth 2012). Thus, we would expect to 
see variation in responses to SC if forest cover, sedimentation, or other factors were determining patterns of salamander occupancy and abundance across the SC gradient. Instead, we found similar responses to SC across species and life stages, which suggests that SC may be strongly associated with patterns of occupancy and abundance in the study area. We note, however, that SC is a measure related to the concentration of ions in the water and that a specific ion or ions may be the causal factor responsible for patterns of salamander occupancy and abundance.

If SC drives patterns of salamander occupancy and abundance in Central Appalachian streams, restoration activities may need to emphasize repairing water chemistry. Current restoration activities on MTR-VF sites focus on restoring native forests (Angel et al. 2005). Although reforestation will clearly benefit some salamander species and ameliorate some water quality issues, failure to address elevated ionic composition may prevent recovery of stream salamander populations in streams affected by MTR-VF. Treatment methods such as desalinization or stream creation may be necessary to restore habitat because elevated SC persists for decades in streams draining MTR-VF sites (Merricks et al. 2007, Pond et al. 2008). However, to further tease out the influence of elevated SC on salamander populations, physiological and dietary studies should be conducted along the SC gradient to identify the mechanisms behind the patterns of salamander occupancy and abundance observed in our study.

\section{ACKNOWLEDGEMENTS}

Author contributions: JMH, SJP, SCR, and CDB framed ideas and designed the study. JMH and SJP conducted the field work. JMH, SJP, and SJB analyzed the data. All authors contributed to the interpretation of results and writing the manuscript.

Funding for this project was provided by the Kentucky Academy of Science, University of Kentucky Tracy Farmer Institute for Sustainability and the Environment, University of Kentucky Appalachian Center, Eastern Kentucky University Division of Natural Areas, the Society for the Study of Amphibians and Reptiles, Foundation for the Conservation of Salamanders, the Society of Freshwater Science, and the McIntire-Stennis Research Program (accession number 1001968). The Department of Forestry and Natural Resources at the University of Kentucky further provided resources, facilities, and permission for use of Robinson Forest and Laurel Fork Surface Mine. The Eastern Kentucky University Division of Natural Areas provided facilities and access to Lilley Cornett Woods. We thank Andrea N. Drayer, Wendy Leuenberger, Allison Davis, Rebecca Leloudis, and Millie E. Hamilton for assistance with data collection, analysis, and the generation of figures. Research was performed under the University of Kentucky Institutional Animal Care and Use Committee protocol number 2102-1054 and Kentucky Department of Fish and Wildlife Resources permit number SC1711117. This study is contribution number 53 of Lilley Cornett Woods Appalachian Ecological Research Station, Eastern Kentucky University.

\section{LITERATURE CITED}

Angel, P., V. Davis, J. Burger, D. Graves, and C. Zipper. 2005. The Appalachian regional reforestation initiative. Appalachian Regional Reforestation Initiative, United States Office of Surface Mining. Forest Reclamation Advisory No. 1. (Available from: https://arri.osmre.gov/FRA/Advisories/FRA_No.1.7-18-07 .Revised.pdf)

Barbour, R. W. 1950. A new subspecies of the salamander Desmognathus fuscus. Copeia 1950:277-278.

Barrett, K., B. S. Helms, C. Guyer, and J. E. Shoonover. 2010. Linking process to pattern: Causes of stream-breeding amphibian decline in urbanizing watersheds. Biological Conservation 143:1998-2005.

Bernhardt, E. S., B. D. Lutz, R. S. King, J. P. Fay, C. E. Carter, A. M. Helton, D. Campagna, and J. Amos. 2012. How many mountains can we mine? Assessing the regional degradation of Central Appalachian rivers by surface coal mining. Environmental Science \& Technology 46:8115-8122.

Bernhardt, E. S., and M. A. Palmer. 2011. The environmental costs of mountaintop mining valley fill operations for aquatic ecosystems of the Central Appalachians. Annals of the New York Academy of Sciences 1223:39-57.

Brophy, T. R., and T. K. Pauley. 1997. Dietary comparison of Eurycea cirrigera (Southern Two-lined Salamander) larvae from pond and stream habitats in southern West Virginia. Behavioral Neuroscience 6:1019-1029.

Caldwell, R. S., and W. C. Houtcooper. 1973. Food habits of larval Eurycea bislineata. Journal of Herpetology 7:386-388.

Cañedo-Argüelles, M., B. J. Kefford, C. Piscart, N. Prat, R. B. Schäfer, and C. J. Schulz. 2013. Salinisation of rivers: An urgent ecological issue. Environmental Pollution 173:157-167.

Cecala, K. K., J. C. Maerz, B. J. Halstead, J. R. Frisch, T. L. Gragson, J. Hepinstall-Cymerman, D. S. Leigh, C. R. Jackson, J. T. Peterson, and C. M. Pringle. 2018. Multiple drivers, scales, and interactions influence southern Appalachian stream salamander occupancy. Ecosphere 9:e02150.

Cecala, K. K., S. J. Price, and M. E. Dorcas. 2007. The diet of larval Red Salamanders (Pseudotriton ruber) examined using a nonlethal technique. Journal of Herpetology 41:741-745.

Chambers, D. L. 2011. Increased conductivity affects corticosterone levels and prey consumption in larval amphibians. Journal of Herpetology 45:219-223.

Cope, E. D. 1859. On the primary divisions of the Salamandridae, with descriptions of two new species. Proceedings of the Academy of Natural Sciences of Philadelphia 11:122-128.

Cormier, S. M., G. W. Suter, and L. Zheng. 2013. Derivation of a benchmark for freshwater ionic strength. Environmental Toxicology and Chemistry 32:263-271.

Davic, R. D. 1991. Ontogenetic shift in diet of Desmognathus quadramaculatus. Journal of Herpetology 25:108-111.

Dorazio, R. M., J. Martin, and H. H. Edwards. 2013. Estimating abundance while accounting for rarity, correlated behavior and other sources of variation in counts. Ecology 94:1472-1478.

Dunn, E. R. 1916. Two new salamanders of the genus Desmognathus. Proceedings of the Biological Society of Washington 29:73-76.

Dunn, E. R. 1920. Some reptiles and amphibians from Virginia, North Carolina, Tennessee and Alabama. Proceedings of the Biological Society of Washington 33:129-138. 
Fritz, K. M., S. Fulton, B. R. Johnson, C. D. Barton, J. D. Jack, D. A. Word, and R. A. Burke. 2010. Structural and functional characteristics of natural and constructed channels draining a reclaimed mountaintop removal and valley fill coal mine. Journal of the North American Benthological Society 29: 673-689.

Gelman, A. E., and D. B. Rubin. 1992. Inference from iterative simulation using multiple sequences. Statistical Science 7: 457-511.

Gould, P. R., K. K. Cecala, S. S. Drukker, B. A. McKenzie, and C. Van de Ven. 2017. Biogeographical factors affecting the distribution of stream salamanders on the Cumberland Plateau, USA. Science of the Total Environment 599-600:16221629.

Grant, E. H. C., L. E. Green, and W. H. Lowe. 2009. Salamander occupancy in headwater stream networks. Freshwater Biology 54:1370-1378.

Grant, E. H. C., D. A. W. Miller, B. R. Schmidt, M. J. Adams, S. M. Amburgey, T. Chambert, S. S. Cruickshank, R. N. Fisher, D. M. Green, B. R. Hossack, P. T. J. Johnson, M. B. Joseph, T. Rittenhouse, M. Ryan, J. H. Waddle, S. C. Walls, L. L. Bailey, G. M. Fellers, T. A. Gorman, A. M. Ray, D. S. Pilliod, S. J. Price, D. Saenz, and E. Muths. 2016. Quantitative evidence for the effects of multiple drivers on continental-scale amphibian declines. Scientific Reports 6:25625.

Green, J. 1818. Descriptions of several species of North American Amphibia, accompanied with observations. Journal of the Academy of Natural Sciences of Philadelphia 1:348-359.

Green, J. 1827. An account of some new species of salamanders. Contributions of the Maclurian Lyceum to the Arts and Sciences 1:3-8.

Green, J. 1831. Description of two new species of salamander. Journal of the Academy of Natural Sciences of Philadelphia 6:253-255.

Greenberg, A. E., L. S. Clesceri, and A. D. Eaton. 1992. Standard methods for the examination of water and wastewater. $18^{\text {th }}$ edition. American Public Health Association, Washington, DC.

Griffith, M. B., S. B. Norton, L. C. Alexander, A. I. Pollard, and S. D. LeDuc. 2012. The effects of mountaintop mines and valley fills on the physicochemical quality of stream ecosystems in the central Appalachians: A review. Science of the Total Environment 417:1-12.

Hartman, K. J., M. D. Kaller, and J. W. Howell. 2005. How much do valley fills influence headwater streams? Hydrobiologia 532:91-102.

Hassell, K. L., B. J. Kefford, and D. Nugegoda. 2006. Sub-lethal and chronic salinity tolerances of three freshwater insects: Cloeon sp. and Centroptilim sp. (Ephemeroptera: Baetidae) and Chironomus sp. (Diptera: Chrionomidae). Journal of Experimental Biology 209:4024-4032.

Hitt, N. P., and D. B. Chambers. 2014. Temporal changes in taxonomic and functional diversity of fish assemblages downstream from mountaintop mining. Freshwater Science 33: 915-926.

Hitt, N. P., M. Floyd, M. Compton, and K. McDonald. 2016. Threshold responses of Blackside Dace (Chrosomus cumberlandensis) and Kentucky Arrow Darter (Etheostoma spilotum) to stream conductivity. Southeastern Naturalist 15:4160.
Holbrook, J. E. 1840. North American herpetology; or description of the reptiles inhabiting the United States. $1^{\text {st }}$ edition. Volume 4. J. Dobson, Philadelphia, Pennsylvania.

Hutton, J. M., S. J. Price, and S. C. Richter. 2018. Diet of the Black Mountain Salamander (Desmognathus welteri) in southeastern Kentucky. Herpetological Review 49:12-19.

Johnson, B. R., and J. B. Wallace. 2005. Bottom-up limitation of a stream salamander in a detritus-based food web. Canadian Journal of Fisheries and Aquatic Sciences 62:301-311.

Karraker, N. E., J. P. Gibbs, and J. R. Vonesh. 2008. Impacts of road deicing salt on the demography of vernal pool-breeding amphibians. Ecological Applications 18:724-734.

Kaushal, S. S., G. E. Likens, M. L. Pace, R. M. Utz, S. Haq, J. Gorman, and M. Grese. 2018. Freshwater salinization syndrome on a continental scale. Proceedings of the National Academy of Sciences 115:E574-E583.

Keitzer, C. S., and R. R. Goforth. 2012. Response of streambreeding salamander larvae to sediment deposition in southern Appalachian (USA) headwater streams. Freshwater Biology 57:1535-1544.

Kennedy, A. J., D. S. Cherry, and R. J. Currie. 2003. Field and laboratory assessment of a coal processing effluent in the Leading Creek Watershed, Meigs County, Ohio. Archives of Environmental Contamination and Toxicology 44:324-331.

Kraus, J. M., J. F. Pomeranz, A. S. Todd, D. M. Walters, T. S. Schmidt, and R. B. Wanty. 2016. Aquatic pollution increases use of terrestrial prey subsidies by stream fish. Journal of Applied Ecology 53:44-53.

LeConte, J. E. 1825. Remarks on the American species of the genera Hyla and Rana. Annals of the Lyceum of Natural History of New York 1:278-282.

Lindberg, T. T., E. S. Bernhardt, R. Bier, A. M. Helton, R. B. Merola, A. Wengosh, and R. T. DiGiulio. 2011. Cumulative impacts of mountaintop mining on an Appalachian watershed. Proceedings of the National Academy of Science 108: 20929-20934.

Lowe, W. H., K. H. Nislow, and D. T. Bolger. 2004. Stage-specific and interactive effects of sedimentation and trout on a headwater stream salamander. Ecological Applications 14:164-172.

Martin, W. H. 1975. The Lilley Cornett Woods: A stable mixed mesophytic forest in Kentucky. Botanical Gazette 136:171-183.

Martin, W. H., and C. Shepherd. 1973. Trees and shrubs of Lilley Cornett Woods, Letcher County, Kentucky. Castanea 1973: 327-335.

Martof, B. S., and D. C. Scott. 1957. The food of the salamander Leurognathus. Ecology 38:494-501.

McCulloch, W. L., W. L. Goodfellow, and J. A. Black. 1993. Characterization, identification and confirmation of total dissolved solids as effluent toxicants. Environmental Toxicology and Risk Assessment 2:213-227.

Merriam, E. R., J. T. Petty, G. T. Merovich, J. B. Fulton, and M. P. Strager. 2011. Additive effects of mining and residential development on stream conditions in a central Appalachian watershed. Journal of the North American Benthological Society 30: 399-418.

Merricks, T. C., D. S. Cherry, C. E. Zipper, R. J. Currie, and T. W. Valenti. 2007. Coal-mine hollow fill and settling pond influences on headwater streams in southern West Virginia, USA. Environmental Monitoring and Assessment 129:359-378. 
Miller, J. E., G. R. Hess, and C. E. Moorman. 2007. Southern Twolined Salamanders in urbanizing watersheds. Urban Ecosystems 10:73-85.

Muncy, B. L., S. J. Price, S. J. Bonner, and C. D. Barton. 2014. Mountaintop removal mining reduces stream salamander occupancy and richness in southeastern Kentucky (USA). Biological Conservation 180:115-121.

Netting, M. G., and M. B. Mittleman. 1938. Description of Plethodon richmondi, a new salamander from West Virginia and Ohio. Annals of the Carnegie Museum 27:287-293.

Palmer, M. A., E. S. Bernhardt, W. H. Schlesinger, K. N. Eshleman, E. Foufoula-Georgiou, M. S. Hendryx, A. D. Lemly, G. E. Likens, O. L. Loucks, M. E. Power, P. S. White, and P. R. Wilcock. 2010. Mountaintop mining consequences. Science 327:148149.

Phillippi, M. A., and A. Boebinger. 1986. A vegetational analysis of three small watersheds in Robinson Forest, Eastern Kentucky. Castanea 51:11-30.

Plummer, M. 2003. JAGS: A program for analysis of Bayesian graphical models using Gibbs sampling. Pages 1-10 in K. Hornik, F. Leisch, and A. Zeileis (editors). Proceedings of the $3^{\text {rd }}$ International Workshop on Distributed Statistical Computing, Vienna, Austria.

Pond, G. J. 2010. Patterns of Ephemeroptera taxa loss in Appalachian headwater streams (Kentucky, USA). Hydrobiologia 641:185-201.

Pond, G. J. 2012. Biodiversity loss in Appalachian headwater streams (Kentucky, USA): Plecoptera and Trichoptera communities. Hydrobiologia 679:97-117.

Pond, G. J., M. E. Passmore, F. A. Borsuk, L. Reynolds, and C. J. Rose. 2008. Downstream effects of mountaintop coal mining: Comparing biological conditions using family- and genuslevel macroinvertebrate bioassessment tools. Journal of the North American Benthological Society 27:717-737.

Price, S. J., R. A. Browne, and M. E. Dorcas. 2012. Evaluating the effects of urbanisation on salamander abundances using a before-after control-impact design. Freshwater Biology 57:193203.

Price, S. J., K. K. Cecala, R. A. Browne, and M. E. Dorcas. 2011. Effects of urbanization on occupancy of stream salamanders. Conservation Biology 25:547-555.
Price, S. J., S. B. Freytag, S. J. Bonner, A. N. Drayer, B. L. Muncy, J. M. Hutton, and C. D. Barton. 2018. Mountaintop removal mining alters stream salamander population dynamics. Diversity and Distributions 24:1242-1251.

Price, S. J., B. L. Muncy, S. J. Bonner, A. N. Drayer, and C. D. Barton. 2016. Effects of mountaintop removal mining and valley filling on the occupancy and abundance of stream salamanders. Journal of Applied Ecology 53:459-468.

Rafinesque, C. S. 1820. III Class. Erpetia.-The reptiles. Annals of nature: or, annual synopsis of new genera and species of animals, plants, etc. discovered in North America. Privately reprinted by T. J. Fitzpatrick, Iowa City, Iowa.

Sanzo, D., and S. J. Hecnar. 2006. Effects of road de-icing salt $(\mathrm{NaCl})$ on larval Wood Frogs (Rana sylvatica). Environmental Pollution 140:247-256.

Schorr, M. S., M. C. Dyson, C. H. Nelson, G. S. Van Horn, D. E. Collins, and S. M. Richards. 2013. Effects of stream acidification on lotic salamander assemblages in a coal-mined watershed in the Cumberland Plateau. Journal of Freshwater Ecology 28:339-353.

Shaw, G. 1802. General zoology, or systematic natural history. Volume III, part I. Amphibia. G. Kearsley, London, UK.

Shoemaker, V., and K. A. Nagy. 1977. Osmoregulation in amphibians and reptiles. Annual Review of Physiology 39:449-471.

Sonnini, C. S., and P. A. Latreille. 1801. Histoire Naturelle des Reptiles, avec figures dissinées d'après nature. Volume 4. Deterville, Paris, France.

Voss, K. V., and E. S. Bernhardt. 2017. Effects of mountaintop removal coal mining on the diversity and secondary productivity of Appalachian rivers. Limnology and Oceanography 62:17541770.

Wickham, J., P. B. Wood, M. C. Nicholson, W. Jenkins, D. Druckenbrod, G. W. Suter., M. P. Strager, C. Mazzarella, W. Galloway, and J. Amos. 2013. The overlooked terrestrial impacts of mountaintop mining. BioScience 63:335-348.

Wood, P. J., and A. P. Dykes. 2002. The use of salt dilution gauging techniques: Ecological considerations and insights. Water Research 36:2054-3062.

Wood, P. B., and J. M. Williams. 2013. Impact of valley fills on streamside salamanders in southern West Virginia. Journal of Herpetology 47:119-125. 